\title{
Investigation of structure-function interaction of Bombyx mori nuclear polyhedrosis virus polyhedrin with polyhedra protease and RNA. Effect of protease on polyhedrin dissociation during Sepharose 6B gel-filtration.
}

\author{
E.A. Kozlov, N. Nijazova, M.T. Bobrovskaja, T.V. Shirina
}

The Institute of Molecular Biology and Genetics, NAS of Ukraine 150, Acad. Zabolotny Str., Kyiv, 03143, Ukraine

e-mail:kozlov@imbg.org.ua

\begin{abstract}
It is known that B. mori NPV polyhedra contains protease which cleaves polyhedrin polypeptide chain (m.w. $28500)$ during dissolution of polyhedra in vitro under alkaline conditions ( $\mathrm{pH} 10.5$ ) to overlapping fragments with mol. weights 25000, 22000, 19000, 10000, and 8000. Besides, polyhedrin is present in solution at pH 10.5 as high mol. weight $13 \mathrm{~S}-(70 \%)$ and $>13 \mathrm{~S}(30 \%)$ associates. Current paper shows that during Sepharose $6 B$ gel-filtration at $\mathrm{pH} 10.5$ of polyhedrin $\mathrm{pH} 10.5$ solution there occurs partial dissociation of high mol. weight associates to unknown earlier 8.5S-associates, 25000 polypeptide and its dimer with sedimentation coefficient 3.4S. Undissociated high mol. weight associates and 8.5S-associates contain the whole polypeptide chain (m.w. 28500) only. During gel-filtration at $\mathrm{pH} 11.0$ of polyhedrin solution with the same $\mathrm{pH}$ there occurs complete dissociation of high mol. weight associates to 8.5S-associates, 22000 polypeptide and its dimer with sedimentation coefficient 3.2S. The 8.5S-associate contains the whole 28500 polypeptide chain only. RNA was found in the low mol. weight (and high mol. weight (13S and higher) zones). 8.5S-associates do not contain RNA. After preliminary polyhedra heating at $80-90^{\circ} \mathrm{C}$ the polyhedra protease does not cleave polyhedrin in $\mathrm{pH} 10.5$ solution and dissociation of high mol. weight associates to 8.5S-associates containing whole polypeptide chain occurs with much lower degree during gel-filtration at $\mathrm{pH}$ 10.5. Yet as a result of gel-filtration RNP-complex is released with mol. weight of 20000-25000 and sedimentation 2.9S, containing polypeptide chain with mol. weight of 10000-12000. The effect of the polyhedra protease and RNA on in vivo polyhedrin dissociation and virus realization from polyhedra is discussed.
\end{abstract}

Keywords: nuclear polyhedrosis, polyhedrin, association-dissociation, polyhedra protease, polyhedra RNA, RNP-complex, structure-function interaction.

Introduction. Polyhedrin is the incorporation body (IB) protein of nuclear polyhedrosis virus (NPV), representing serum group of DNA-containing family of baculoviruses, which affect insects only. IB NPV has got the polyhedrin shape. The second serum group is

(C) E.A. KOZLOV, N. NIJAZOVA, M.T. BOBROVSKAJA, T.V. SHIRINA, 2006 the granulosis viruses (GV), which make IB granule forms (IB protein - granuline). Polyhedrin, as well as granuline, is a key element in the process of virus infection spreading in the population of insects. Synthesising on the last stage of infectious process, when the formation of virions is being finished (or is 
taking place), polyhedrin is associated in the nucleus of cells and, interacting with membranes of virions, includes multitudes of virus particles into forming crystals (polyhedras). On insects death and decomposition, polyhedras, having occurred in the environment, reveal extraordinary resistance, at the same time preserving the infectivity of virions for several years [1]. On the other hand, having been mixed with food in healthy insect organism, the polyhedras are easily dissolved in intestinal juice ( $\mathrm{pH}$ app 9). Polyhedrin, being dissociated, frees the virions which penetrate intestine cells and initiate contamination process of the whole organism.

It is clearly obvious that effective infection contamination spreading from host to host depends on unique features of polyhedrin association-dissociation mechanism, active at different conditions (association in cell nucleus, dissociation in intestinal juice).

Having analysed the results of chemical and physical-chemical features of IB protein baculoviruses in our multiple previous publications, we can set the goal for our present and future investigations identification of polyhedrin association-dissociation mechanisms and the participation of protease and RNA, included to polyhedrin, in such mechanisms. There is an opinion, that RNA forms the RNP-complex with polyhedrin on the first level of infection transmission (polyhedrin association and formation of polyhedras in the nucleus), assisting polyhedras appearing. A hypothesis on possible influence of RNA polyhedras on association-dissociation processes in in vitro solutions has been set by us in a short communication in 1969 [2]. Since that time researches on this topic have not been conducted. A role of protease in contamination process has also been discussed by us in 1980 [3]. Recently we have published [4] the results of investigation of kinetics of polyhedrin polypeptide chain cleavage, which presuppose that polyhedrin is a natural substrate of protease, included to polyhedrin. This short communication can be considered to be the first in the series of further publications under the common title dedicated to $B$. mori NPV polyhedrin association-dissociation mechanisms, with proteases and polyhedras RNA participation.

Current work presents the data on investigation of influence of polyhedras cleavage by protease in specific sites of B. mori NVP polyhedrin polypeptide chain on polyhedrin dissociation in the gel-filtration process via 6B sepharose ("Pharmacia", Sweden) at the condition of polyhedras dissolution in vitro.

Materials and Methods. Polyhedras. The polyhedras used were isolated from hemolymph of caterpillars of 4th-5th age, NPV infected at laboratory conditions.

Solvents. Solution A, $\mathrm{pH} 10.5,\left(0.05 \mathrm{M} \mathrm{Na}_{2} \mathrm{CO}_{3}+\right.$ $0.05 \mathrm{M} \mathrm{NaHCO}_{3}+0.1 \mathrm{M} \mathrm{NaCl}$ ); Solution B, pH 11.0, $\left(0.04 \mathrm{M} \mathrm{Na}_{2} \mathrm{CO}_{3}+0.014 \mathrm{M} \mathrm{NaHCO}_{3}+0.1 \mathrm{M} \mathrm{NaCl}\right)$.

Polyhedrin solutions. $250 \mathrm{mg}$ of polyhedras were dissolved in $4 \mathrm{ml}$ of solutions A and B for 1 hour at room temperature. Undissolved materials were removed by centrifugation for $5 \mathrm{~min}$ at $6000 \mathrm{rpm}$. Virions and the products of their degradation were removed by further ultra-centrifugation $\left(4^{\circ} \mathrm{C}, 30000\right.$ rpm).

Proteolytic activity inhibition. The polyhedras were slurred in $4 \mathrm{ml}$ of distilled water and left in the fridge for the night. Then, the suspension was hatched being stirred intensively, $80-90^{\circ} \mathrm{C}, 5-10 \mathrm{~min}$.

Gel-filtration was performed using 6B sepharose ("Pharmacia"), molecule division range $10^{4}-4 \cdot 10^{6}$. Gel-filtration conditions are described below the corresponding figure.

Electrophoresis in polyacrylamide gel in the presence of DS-Na was performed using the device "Helicon" (Russia) in 10\% gel in accordance to [5].

Sedimentation analysis was performed using MOM-31706 ultracentrifuge (Hungary) with Schlieren optics registration. The captures were made on maximal speed of $50000 \mathrm{rpm}$ occurrence. Sedimentation coefficient (S) was calculated in accordance to [6].

The RNA content in solutions was determined using orcine reaction [7] and UV-spectra $\left(\mathrm{E}_{260} / \mathrm{E}_{280}\right)$.

UV-spectra adsorptions in the range of 230-320 $\mathrm{nm}$ were recorded by "Specord" (Germany) spectrophotometer.

Results and Discussion. It is commonly known that polyhedras are dissolved in vitro at $\mathrm{pH}-$ level not lower than 10.5 [8]. Polyhedrin is present in $\mathrm{pH} 10.5$ solutions in the form of associates with $13 \mathrm{~S}(70 \%)$, 19S (20\%), and 23S (10\%) sedimentation coefficients [9]. Besides, almost a half of associates contains 

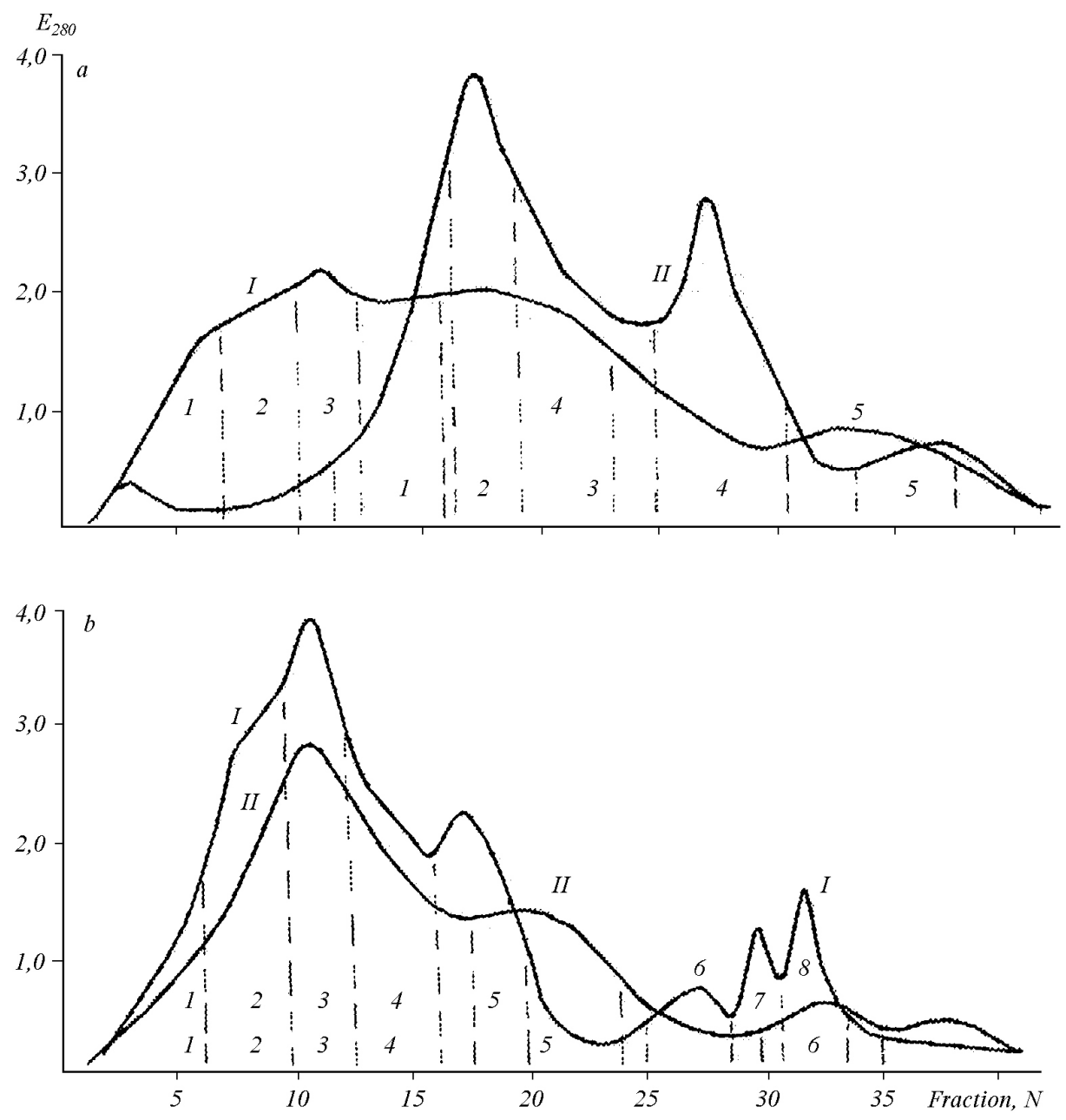

Fig.1. Gel-filtration via sepharose 6B polyhedrin preparations NPV B.mori, obtained by dilution of native (a) and denaturated (b) polyhedras in $\mathrm{pH} 10.5$ and 11.0 solutions. Column $2.0 \times 55$ $\mathrm{cm}$ equilibrated by solutions with $\mathrm{pH}$ 10.5 (I) and $\mathrm{pH} 11.0$ (II). Elution speed - $20 \mathrm{ml}$ per hour, fraction volume $-3 \mathrm{ml}$. Zones marked by dotted lines and figures are the ones selected for further investigations after gel-filtration at $\mathrm{pH} 10.5$ (top row of figures at each Figures) and $\mathrm{pH}$ 11.0 (bottom row).

polypeptide chains with polypeptide bounds partially split in seven centres, which was determined by us earlier [4]. Nevertheless, 13S-associates dissociation does not take place at $\mathrm{pH} 10.5$ [2]. However, subsequent $\mathrm{pH}$ increase to 11.0 results in partial dissociation of $13 \mathrm{~S}$-associate to the component with average sedimentation coefficient $2.7 \mathrm{~S}$ [2].

It may be supposed that it is polyhedrin dimer, taking into account the fact that monomer has sedimentation coefficient 1.6S [9]. Apparently, the reason for dissociation is not only in wider openness of the centres of split by protease at $\mathrm{pH} 11.0$, but in the presence of RNA, which is capable of dissociating with polyhedrin [9].

To solve this matter, we used macroporous gel sepharose 6B (we used Sephadex G-25 in the past [3]).
Polyhedrin solutions pH 10.5 and 11.0, obtained of polyhedras with inhibited (denaturation of polyhedra) and active (native polyhedras) proteases, were subjected to gel-filtration. Fig. 1 shows that $0.5 \mathrm{pH}$ alteration results in rapid polyhedrin dissociation in the case with native (Fig.1, a) and in the case with warming-up of the denaturated ones - in the less noticed one (Fig.1, b.). The issue clears up analysing the sedimentograms selected after gel-filtration (Fig.2). Using native polyhedras at $\mathrm{pH} 10.5$ as a result of gel-filtration partial dissociation 13S-associate (Fig.2, a) down to 7.5S- and 3.4S-associates (Fig.2, b, c) takes place. At $\mathrm{pH}$ increase at $13 \mathrm{~S}$-associate gel-filtration (Fig.2, d) is completely dissociated to 8.5S- and 3.2S-associates (Fig.2, e, f). In the case of denaturated polyhedras, only partial dissociation of 

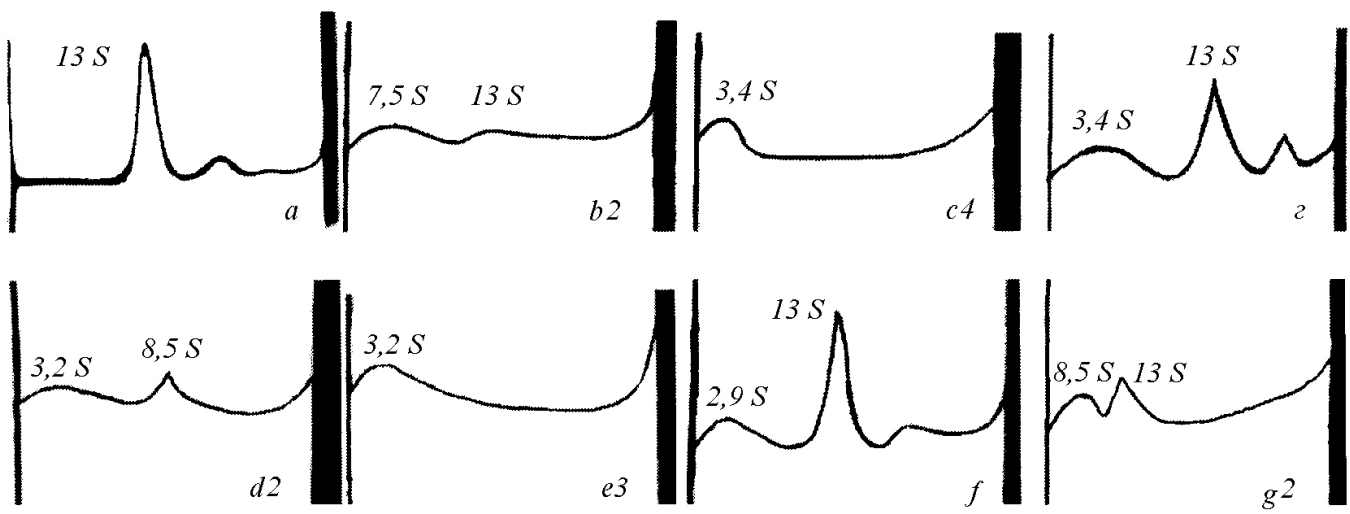

Fig.2. Sedimentograms of initial polyhedrin solutions of native (a, d) and denaturated $(\mathrm{g}, \mathrm{i})$ and 11.0 $(d, i)$, as well as the zones, obtained after gel-filtration of initial solutions of native (b, c, e,

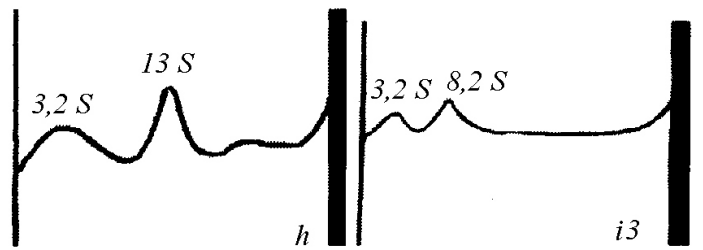

f) and denaturated $(\mathrm{h}, \mathrm{j})$ of polyhedras at $\mathrm{pH} 10.5(\mathrm{~b}$, $\mathrm{c}, \mathrm{h})$ and $\mathrm{pH} 11.0(\mathrm{e}, \mathrm{f}, \mathrm{j})$. Figures indicators at some letters determine the zones selected for the investigation after gel-filtration (Fig.1). S sedimentation coefficient.

13S-associate (Fig.2, g) to 8.5S-associate (Fig.2, h) occurs. 3.2S-associate is revealed only at $\mathrm{pH}$ increase up to 11 (Fig. 2, j). The mentioned facts are proved by gel-filtration data (Fig.1). At pH 10.5 output volume of zone 5 (Fig. 1, b) is equal to the same of zone 2 at $\mathrm{pH}$ 11.0 native polyhedras (Fig.1, a), sedimentation coefficient 8.5S (Fig.2, e). The zone corresponding sedimentation coefficient $3.2 \mathrm{~S}$ at $\mathrm{pH} 10.5$ is absent (Fig.1, b). However, as it is seen in the same Fig., zone 5 appears at $\mathrm{pH} 11.0$, output volume of which is equal to zone 4 volume at $\mathrm{pH} 10.5$ native polyhedras (Fig.1, a), sedimentation coefficient $3.4 \mathrm{~S}$.

It is worth mentioning that in all four polyhedrin initial solutions 7.5S-8.5S-associates are absent (Fig.2, a, d, g, i) and in initial solutions at $\mathrm{pH} 10.5$ there are no 3.2S-3.4S-associates (Fig.2, a, g). The discussion on the nature and presence of 2.9S-component in denaturated polyhedras initial solution, $\mathrm{pH}$ 10.5, (Fig.2, g in comparison with Fig.2, a) as well as its absence after gel-filtration (Fig.1, b) will be held later, in the connection with RNA analysis in zones after gel-filtration. If all four polyhedrin initial solutions are left not only for the time equal to the time of gel-filtration but for 24 hours, then their sedimentograms are not changed. The sedimentograms are not changed at 5-10-fold dilution (analogous to gel-filtration). It is evident that the associates with sedimentation coefficient $<13 \mathrm{~S}$ appear in the process of gel-filtration. Such polyhedrin behaviour at gel-filtration can be partially revealed at DS-Na-PAAG zones electrophoregram investigation (Fig.3) selected after gel-filtration (Fig.1).

Fig.1, a, b shows that polyhedrin polypeptide chain, obtained as a result of native polyhedras dilution at $\mathrm{pH}$ 10.5 and 11.0 is cleaved significantly to fragments 22000 and $25000 \mathrm{~m} . \mathrm{w}$. by polyhedra protease. As it is seen from previously reported [4], polypeptide chain fragments 25000 and $22000 \mathrm{~m} . \mathrm{w}$. are the fragments without 36 and 58 residues from C-end,1-209 and 1-186 respectively, i.e. without one of two C-ends, responsible for protein-protein interactions in accordance to our hypothesis about structural and functional organisation of polyhedrin polypeptide chain [9]. The quantity of such fragments increases from high-molecular zone (13S and on, Fig.2, a; Fig.3, a, lines 1,2) to low-molecular (3.2S Fig.2, c; Fig.3, a, 


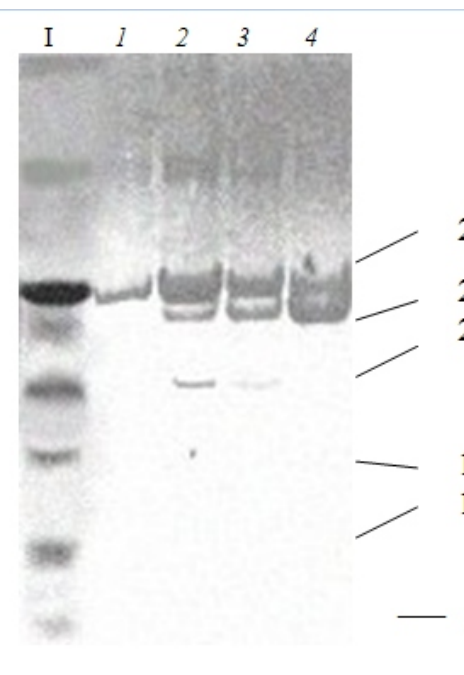

$I$

I

$\begin{array}{llll}1 & 2 & 3 & 4\end{array}$

$a$

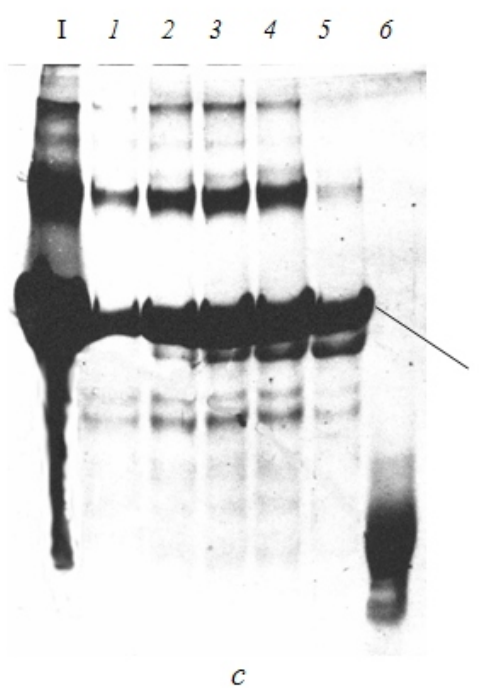

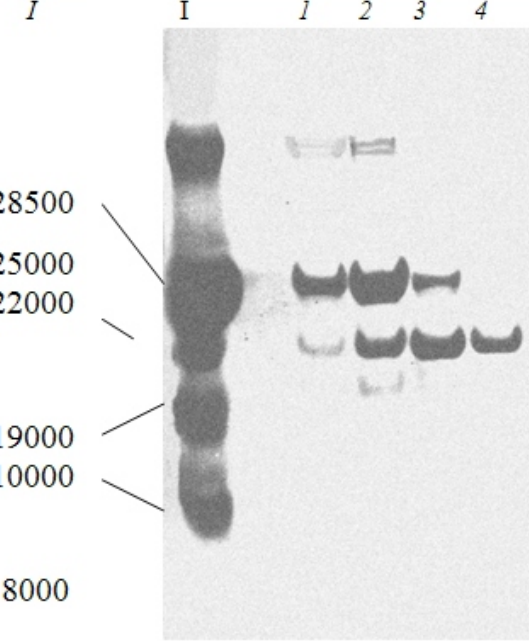

$b$

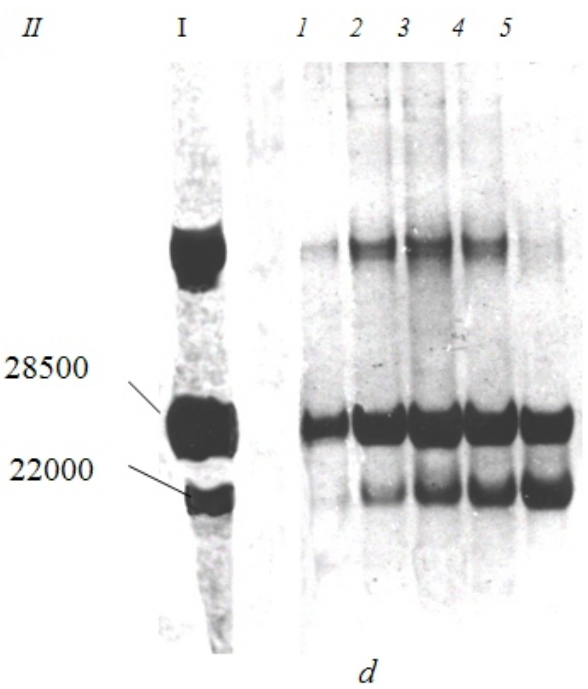

Fig.3. Electrophoresis in the polyhedrin initial solutions in DS-Na-PAAG, obtained using native (I) and denaturated (II) polyhedras in the solutions at $\mathrm{pH} 10.5(\mathrm{a}, \mathrm{c})$ and $\mathrm{pH} 11.0(\mathrm{~b}, \mathrm{~d})$. Numbers on lines correspond to marking of zones, selected for the analysis after gel-filtration (Fig.1). line 4) after gel-filtration. It is specific for $22000 \mathrm{~m} . \mathrm{w}$. fragment, which appears in polyhedrin solutions at $\mathrm{pH}$ 11.0 (Fig.3, b, lines 1, 4), whereas only this fragment is present in zone 4 . The presence of complete polypeptide chain m.w. 28500 in zone 3, containing 3.2S-associate (Fig.2, f), is explained by the presence of insignificant amount of 8.5S-associate (Fig.1, a), which can not be revealed by centrifugation, but is detected in the neighbouring zone 2, covered by zone 3 (Fig.1, a, II; Fig.2, e). The presence of insignificant amounts of fragments with 25000 and $22000 \mathrm{~m}$.w. in high-molecular zones 1 and 2 (Fig.3, a, b, lines 1,2) is explained by polyhedrin dissociation in the process of gel-filtration (mentioned above). It is possible that low-molecular associates appear at gel-filtration in zones with high-molecular associates due to the same reason (Fig. 2, b, e, f, j).

It is obvious that at partial (fragment 1-209), as well as at complete (fragment 1-186), C-end cleavage, responsible for protein-protein interactions, weakening of interactions of polypeptide chains in 13S-associate occurs which leads to its dissociation at the interaction with gel matrix in the process of gel-filtration. Nevertheless, the capability of polyhedrin to form the dimer after C-end 187-244 cleavage is preserved (Fig.1, a, I, zone 4; Fig.1, b, II, zone 3; Fig.2, c, f, respectively). It seems like the interaction of shortened polypeptide chains takes 
place due to the second area $90-120$, which is also responsible for protein-protein interactions [9].

It is also noteworthy that only a half of polyhedrin is dissociated to dimer and monomer, the remaining half (even at $\mathrm{pH} 11.0$ ) is dissociated to $8.5 \mathrm{~S}$-associate containing the complete polypeptide chain (Fig.1, a, II, zones 1,2). It is correlated with the fact that only a half of polyhedrin in the solutions with $\mathrm{pH} 10.5$ contains the cleaved polypeptide chains. It is obvious that not all 12 polypeptide chains (polyhedrin monomers) in $13 \mathrm{~S}$-associate contact with solvent. In our further researches we will try to combine the data obtained by us with existent models of monomers lay-outs in $13 \mathrm{~S}$-associate $[10,11]$.

The fact that polyhedrin dissociation to dimers and on required $\mathrm{C}$-end fragment cleavage is proved by DS-Na-PAAG polyhedrin electrophoresis data of the warmed up polyhedras. The results are shown in Fig.3, $c$, d. The fact is that in the case of completely proteolytic activity absence at $\mathrm{pH} 10.5$ (Fig.3, c) the dimers are not detected at gel-filtration (Fig.1, b, I, Fig.2, f). However, 2.9S-component is detected at ultra-centrifugation (Fig.2, g). The nature of such phenomenon will be mentioned later at RNA connection discussion. The dimers are observed at gel-filtration at pH 11.0 (Fig.1, b, II, zone 5, Fig.2, j), the proteolytic activity is also observed in the solution (Fig.3, d,). It seems that proteolytic activity induction in the warmed up polyhedras is the reason of 3.2S-dimer occurrence at ultra-centrifugation of polyhedrin initial solutions, $\mathrm{pH} 11.0$ (Fig.2, i). The occurrence of proteolytic activity at $\mathrm{pH} 11.0$ in the warmed up polyhedras may be explained by the fact that protease activity, maximally revealed, as it is known, in membranes of virions [12], is not inactivated completely at polyhedras warming up. It is also known [13] that $\mathrm{pH}$ increase to $\mathrm{pH} 11.0$ results in higher degree virions destruction and the transition of active protease from membranes to the solution and to polyhedrin cleavage.

As it was mentioned above, the protease may not be the only possible factor influencing the association-dissociation process of polyhedrin in alkaline solution. We have checked on the issue of RNA presence in all zones, obtained at gel-filtration (Fig.1, a, b). RNA presence was tested by orcine reaction and $\mathrm{E}_{260} / \mathrm{E}_{280} . \mathrm{E}_{260} / \mathrm{E}_{280}$ ratio of polyhedras RNA is 1.85 , and polyhedrin -0.75 [2]. Orcine reaction to RNA was detected in all zones containing 13S- and higher associates. These zones were detected to have maximal protein spectrum at $280 \mathrm{~nm}$ (Fig.4, I). However, $\mathrm{E}_{260} / \mathrm{E}_{280}$ of zones containing $13 \mathrm{~S}$ - and higher associates was $0.8-0.9$, and 0.60 - for zones $7.5 \mathrm{~S}-8.5 \mathrm{~S}$ and 3.2S-3.4S-associates. The presence of RNA in the zones containing high-molecular associates was detected clearly at gel-filtration of native polyhedras solutions at $\mathrm{pH} 10.5$ only (Fig.1, a), i.e. UV-spectra of zone 1, $\mathrm{E}_{260} / \mathrm{E}_{280}=1.15$ (Fig.4, curve 2). Low-molecular zone 5 (Fig.1, a, I) also contains RNA, judging by orcine reaction and UV-spectrum (Fig.4, curve 3), $\mathrm{E}_{260} / \mathrm{E}_{280}=1.10$. At gel-filtration of native polyhedras solutions $\mathrm{pH} 11.0$, the zones containing 13S- and higher associates are absent (Fig.1, a, II), and RNA is detected in zone 5 only, probably, containing the mixture of oligonucleotides (RNA degradation products) and small peptides (products of polyhedrin degradation by protease of polyhedras), $\mathrm{E}_{260} / \mathrm{E}_{280}=1.40$ as well as pH 10.5 zone (UV-spectrum Fig.4, curve 4).

Some interesting results were obtained at gel-filtration of polyhedrin solutions out of polyhedras warming up denaturated. Fig.2, g, shows that at the dilution in the initial solution $\mathrm{pH} 10.5$ the component with $2.9 \mathrm{~S}$ sedimentation coefficient is present, however, it is absent in the same solution of native polyhedras (Fig.2, a). It is obvious that the component has m.w. 30000, as sedimentation coefficient of polyhedrin monomer with m.w. 28500 equals 1.6S [9]. At the same time, at gel-filtration of initial solution of denaturated polyhedras $\mathrm{pH} 10.5$, such component is not detected, though three low-molecular components appear instead (Fig.1, b, I, peaks $6,7,8)$. Molecular weight of 6 peak component is 20000-25000, as this component output volume, at which polyhedrin polypeptide chain fragment is eluted with m.w. 22000 (Fig. 1, a, II, zone 4; Fig.3, b, line 4). Let us compare it with $3.2 \mathrm{~S}$ dimer output volume (Fig.1, a, II, zone 3; Fig.2, f; Fig.3, b, line 3). Polypeptide m.w. 10000-12000 is revealed at peak 6 moment in DS-Na-PAAG (Fig.3, c, line 6). The UV-spectrum of this component has the typical RNA spectrum with maximum of $260 \mathrm{~nm}$ and $\mathrm{E}_{260} / \mathrm{E}_{280}=1.7$. Apparently, peak 6 material is presented by small 


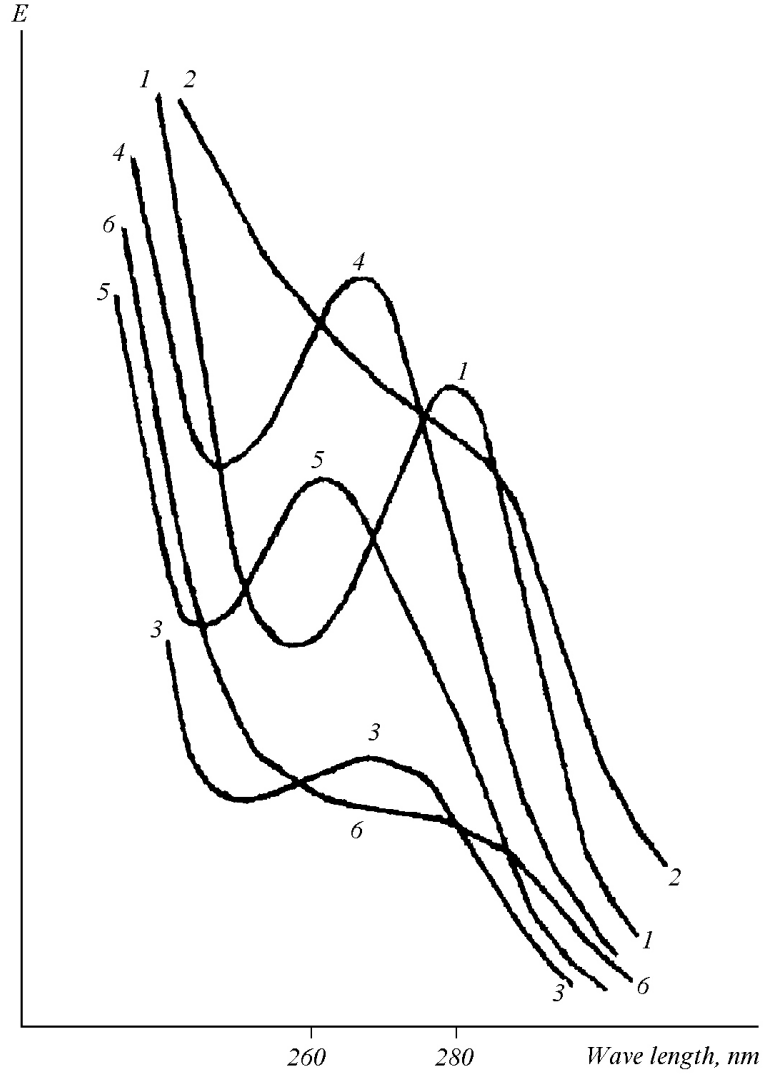

Fig.4. UV-spectra of zones, selected after gel-filtration (Fig.1). Curve markings are in the text.

RNP-complex. It is proved by the fact that the component disappears at $\mathrm{pH} 11.0$ gel-filtration (profiles of curve I and II Fig.1, b), at the same time, peak 6 (Fig.1, b, II), material of which has $\mathrm{UV}$-spectrum with maximum $260 \mathrm{~nm}$ and $\mathrm{E}_{260} / \mathrm{E}_{280}=1.6$ (spectrum is the same as that of RNP-complex, Fig.4, curve 5), representing the mixture of polypeptide with minor RNA, appears again. Most likely, 2.9S-component, present in the initial solution (Fig.2, g) represents the dimer of minor RNP-complex. It is possible to suppose that at the polyhedras dilution, the mentioned dimer is dissociated out of high-molecular (13S and higher) associates, which may be conditioned by the weakening of hydrophobic interactions at warming up of polyhedras. Not only 2.9S dimer appears at gel-filtration of RNP-complex, $\mathrm{pH} 10.5$, but its further partial dissociation to composite components - polypeptide and RNA (Fig.1, b, curve I, peaks 7 and 8), comparable by m.w. - takes place. It is proved by UV-spectra of peaks 7 and 8 - the first one has got typical protein spectrum with $\mathrm{E}_{260} / \mathrm{E}_{280}=0.8$ (data were not presented), the second one, apparently, represents the mixture of polypeptide with oligonucleotide (Fig.4, curve 6, shows the spectrum with $\left.\mathrm{E}_{260} / \mathrm{E}_{280}=1.15\right)$. The fact of dissociation of minor RNP-complex is proven at gel-filtration at pH 11.0 mentioned above. Minor RNP-complex is perhaps realized in the case of dilution of native polyhedras at $\mathrm{pH} 10.5$. However, at gel-filtration of initial solution it can be masked by the appearance of larger quantities of polyhedrin fragments, which occur as a result of polyhedras protease action (Fig.1, a, I). RNP-complex must be eluted somewhere between zones 4 and 5 . The data about this fact were reported in 1969 [2]. In the work cited the minor RNP-complex is determined at gel-filtration at $\mathrm{pH} 10.0$ via sedaphex G-25 (Fig.1, [2], column 3.5x38 cm, fractions 30-38, fraction volume $-5 \mathrm{ml}$ ). At $\mathrm{pH}$ increase to 11.0, oligonucleotides occur instead of RNP-complex (Fig.3, [2], fractions 39-49). pH decrease from 11.0 to 7.2 results in reassociation of nucleotides and polypeptides as well as RNP-complex occurrence (Fig.5, [2], fractions 29-38). Polyhedrin is taken out of the column in fractions 20-28, salt - 75-80. Partial dissociation of 13S-associate to 8.5S-associate (Fig.1, b, I, zone 5) is revealed to take place simultaneously with minor RNP-complex dissociation of warmed up polyhedras during gel-filtration at $\mathrm{pH}$ 10.5. At the same time high-molecular zone 1, apparently, contains RNA (positive orcine reaction, $\mathrm{E}_{260} / \mathrm{E}_{280}=0.9$ ). Complete dissociation 13S- to 8.5S-associate (Fig.1, b, II; Fig.2, j) is observed to take place in warmed up polyhedras at $\mathrm{pH}$ 11.0. Zone 1 may also contain RNA (positive orcine reaction, $\mathrm{E}_{260} / \mathrm{E}_{280}=0.8$ ). Complete dissociation is explained, perhaps, not by $\mathrm{pH}$ increase only, but by the presence of protease activity at $\mathrm{pH}$ 11.0 (explanation is mentioned above).

Conclusions. Some conclusions can be made out of the analysis of conducted research, which are of interest for understanding of the mechanisms of polyhedras dissociation and the virions leading out in vivo on the first stages of contamination of the organism. Polyhedras contain at least one minor RNP-complex with m.w. 20000-25000, which includes polypeptide with m.w. 10000-12000. Disintegration of polyhedras and polyhedrin 
dissociation take place via intermediate associates, the minimal of which has got the sedimentation coefficient of 13S. Further dissociation of such associates takes place with the participation of protease, which cleaves $\mathrm{C}$-end fragment, containing 58 amino acid residues, from polypeptide chain in 13S-associate, and at the same time assists the dissociation of $13 \mathrm{~S}$-associate via $3.2 \mathrm{~S}$-dimer to polypeptide fragments and $8.5 \mathrm{~S}$-associate with simultaneous releasing of virions and minor RNP-complex with m.w. 20000-25000. The destiny and designation of $8.5 \mathrm{~S}$-associate as well as minor NRP-complex are not clear.

There is a series of questions which come out of the research conducted - what is the nature and origin of minor RNP-complex and its components - minor RNA and the polypeptide with m.w. 10000-12000? Are the mentioned components present in the complex in initial polyhedras or are they the by-products of degradation at intestinal alkaline conditions, which take place by the participation of polyhedras protease, polyhedrin high-molecular associates with high-molecular RNA? Due to combined influence of both protease and RNA on the results of conducted experiments the input of RNA (RNP-complex) to the association-dissociation process is not clear. This question can be solved in the course of similar investigations, during which protease proteolytic activity is either absent or significantly decreased, whereas the inactivation of protease by warming up of polyhedras results in denaturation and RNP-complex release. Our farther investigations will be dedicated to clearing up these issues.

\section{Э. А. Козлов, Н. Ниязова, М. Т. Бобровская, Т. В. Ширина}

Исследование структурно-функциональных взаимодействий полиэдрина вируса ядерного полиэдроза тутового шелкопряда Bombyx mori c протеазой и РНК полиэдров. Влияние протеазы на диссоциацию полиэдрина в процессе гель-фильтрации через сефарозу 6В

\section{Резюме}

Известно, что полиэдры ВЯП В. тогі содержат щелочную протеазу, расщепляющую в условиях растворения полиэдров in vitro $(\mathrm{pH} 10,5)$ полипептидную иепь полиэдрина (молекулярная масса (м. м.) 28500) до перекрываюшихся фрагментов с м. м. 25000, 22000, 19000, 10000 и 8000. При этом полиэдрин в растворе с рН 10,5 существует в виде высокомолекулярных 13S- (70 \%) и >13S- (30\%) ассоииатов. Показано, что в прочессе гель-фильтрачии при рН 10,5 через сефарозу 6В раствора полиэдрина с рН 10,5 происходит частичная диссоциация высокомолекулярных ассоџиатов до ранее неизвестного 8,5S-ассоииата, полипептида см.м. 25000 и его димера с коэффиииентом седиментации 3,4S. Причем недиссочиированные высокомолекулярные ассочиаты и 8,5S-ассочиат содержат только иелую полипептидную иель (м. м. 28500). В прочессе гель-фильтрации при рН 11,0 растворов полиэдрина с тем же значением рН происходит полная диссоциация высокомолекулярных ассочиатов до 8,5S-ассочиата, полипептида см. м. 22000 и его димера с коэффициентом седиментации 3,2S. 8,5S-ассоциат также содержит только иелую полипептидную цеепь. РНК в проиессе гель-фильтрации в обоих случаях обнаруживается в высокомолекулярной (13S и более) и низкомолекулярной (м. м. <25000) зонах. 8,5S-ассоииат не содержит РНК. После предварительного подогрева полиэдров при температуре 80-90 ${ }^{\circ} \mathrm{C}$ протеаза не расщепляет полиэдрина в растворе с рН 10,5. В прочессе гель-фильтрации при рН 10,5 таких растворов диссоииачия высокомолекулярных ассоииатов до 8,5S-ассоииата с иелой полипептидной цепью происходит в значительно меньшей степени, но при этом отделяется мальй РНП-комплекс с м. м. 20000-25000 и коэффициентом седиментации 2,9S, включающий полипептид с м. м. 10000-12000. Обсуждается влияние протеазы и РНК на диссоциациию полиэдрина и высвобождение вирионов из полиэдров при растворении их in vivo.

Ключевые слова: вирус ядерного полиэдроза, полиэдрин, ассочиачия-диссочиачия, протеаза полиэдров, РНК полиэдров, РНП-комплекс, структурно-функииональное взаимодействие.

\section{REFERENCES:}

1. Жимерикин В. Н. Некоторые свойства вируса Birdia diprionis штамм «Томский» // Вирусы насекомых / Под ред. Н. Н. Воробьева, Л. М. Тарасевич.-М.: Наука, 1975.-197 с.

2. Козлов Э. А., Согуляева В. М., Левитина Т. Л., Верещак В., Серебряный C. Б. Очистка полиэдренного белка вируса ядерного полиэдроза тутового шелкопряда и исследование процессов его ассоциации-диссоциации в растворах // Биохимия.-1969.-34, № 4.-C. 679-684.

3. Козлов Э. А., Унгуряну Н., Серебряный С. Б. Возможная роль протеазы в вирионах вируса ядерного полиэдроза тутового шелкопряда // Вирусные болезни растений и насекомых: Тр. ЛСХА.-Елгава, 1980.-Вып. 121.-С. 45-48.

4. Бобровская М. Т., Ковалев В. А., Ширина Т. В., Руденко А. В., Козлов Э. А. Динамика расщепления протеазой полиэдров полиэдрина вируса ядерного полиэдроза тутового шелкопряда (Bombyx mori) и идентификация расщепляемых связей // Біополімери і клітина.-2004.-20, № 3.-С. 207-209.

5. Weber K., Osborn M. The reliabiliity of molecular weight determination by dodecyl sulfate polyacrylamid gel electrophoresis // J. Biol. Chem.-1969.-244.-P. 4406-4412.

6. Боуэн T. Введение в ультрацентрифугирование.-М.: Мир, 1973. $-248 \mathrm{c}$

7. Мейбаум В. В. Определение пентоз в нуклеотидах и нуклеозидах посредством реакции Биаля // Биохимия.-1945.-10, № 5.-С. 353-359.

8. Bergold G. H. Die isolierung des poliedervirus und die natur der polieder // Z. Naturforsch.-1947.-2b.-P. 122-143.

9. Kozlov E. A., Levitina T. L., Gusak N. M. The primary structure of aculovirus inclusion body proteins. Evolution and structure-function aspects // Curr. Top. Microbiol. and Immunol.-1986.-131.-P. 135-164.

10. Harrap K. A. The structure of nuclear polyhedrosis virus. I. The inclusion body // Virology.-1972.-50.-P. 114-123.

11. Лыло В. В., Серебряный С. Б. Гидродинамические характеристики $12 \mathrm{~S}$-олигомера белка тел включений вируса ядерного полиэд- 
роза Bombyx mori и модель его структуры в растворе // Биополимеры и клетка.-1988.-4, № 3.-С.139-144.

12. Payne C. C., Kalmakoff J. Alkaline protease associated with virus articles of a nuclear polyhedrosis virus: assay, purification and properties // J. Virol.-1978.-26.-P. 84-92.
13. Козлов Э. А., Серебряный С. Б. Деградация вируса ядерного полиэдроза тутового шелкопряда // Микробиол. журн.-1980.-42, № 3.-C. 365-371.

Надійшла до редакці1 25.01.06 